\title{
Variation of seed sizes and its effect on germination and seedling growth of mahogany (Swietenia macrophylla)
}

\author{
AGUS ASTHO PRAMONO, DIDA SYAMSUWIDA", KURNIAWATI PURWAKA PUTRI"v \\ Center for Research and Development of Forest Tree Seed Technology. Jl. Pakuan Ciheuleut PO Box 105, Bogor, Indonesia. \\ Tel./fax.: +62-251-8327768, `email: dida_syam@yahoo.co.id; •"niapurwaka70@gmail.com \\ Manuscript received: 19 March 2019. Revision accepted: 21 August 2019.
}

\begin{abstract}
Pramono AA, Syamsuwida D, Putri KP. 2019. Variation of seed sizes and its effect on germination and seedling growth of mahogany (Swietenia macrophylla). Biodiversitas 20: 2576-2582. To get high-quality seeds, the size of seed is often suggested to be criteria of selection in seed collection. However, the size is not always effective to be used as a basis for seed selection. The study is aimed to determine the variation of mahogany (Swietenia macrophylla) seed sizes and its effect on the germination and seedlings growth. The fruits were collected from stands of mahogany in Jonggol and Parung Panjang, Bogor District, Indonesia. The seeds were grouped into 5 classes based on seed size. The observation was conducted on seed viability of each size class as well as the growth of seedlings until 3 months old. The results showed that the seed size of mahogany was affected by position of the seeds inside the fruit, the mother trees, and fruit size. The seeds size of $<6 \mathrm{~cm}$ long had significantly lower germination rate and capacity than those seeds of more than $6 \mathrm{~cm}$ long. The size of seeds affected the initial growth of seedlings, but did not influence the subsequent growth of seedling after 3 months old. The selection of seeds was done by removing the seeds of less than $6 \mathrm{~cm}$ long.
\end{abstract}

Keywords: Germination capacity, germination rate, mahogany, seedling, seed selection

\section{INTRODUCTION}

The decree of Indonesian Minister of Forestry No. 707/Menhut-II/2013 has determined five species of forest trees which planting is supposed to use superior seeds collected from certified seed sources, and one of them is mahogany. However, the production of seeds produced from certified seed sources has not fulfilled the target of national plantation yet. Therefore, an attempt is needed to optimize the fulfillment of mahogany seed stock for establishment and rehabilitation of forests and lands.

To obtain high quality seeds, the size of the seeds is often suggested as a selection criterion for seed collection activities, for example in a case of Mimoseps elengi (Suita and Nurhasybi 2008), Macadamia sp. (Heryana et al. 2008), Calophyllum inophyllum (Hasnah 2013), and Intsia bijuga (Wulandari et al. 2015). Mostly, small seed sizes are not used as high-quality seeds. Several research reports found that seed size affected the rate of germination and growth of some crops and forest tree species. Bigger-sized seeds of Mimoseps elengi possessed a greater rate of germination and growth compared to smaller-sized seeds (Suita and Nurhasybi 2008). As well as, small seeds of Thlaspi arvense (Susko and Cavers 2008) and Macadamia sp. (Heryana et al. 2008) significantly influenced the low rate of germination and growth.

However, the size of seeds does not always effective to be a basic of seed sortation. Several studies indicate the need for caution in applying seed size as a sortation criterion. For instance, in soybeans, choosing bigger-sized seeds will result in lower quality seeds after being stored, compared to normal or small seeds. Bigger seeds of soybean have higher moisture content that lowers the seed germination than the small ones (Yulyatin and Diratmaja, 2015). The variation of seed size, seed weight and seed germination of Dalbergia sissoo Roxb were affected dominantly by the differences of clone. The appearance of small seeds as good as large seeds, thus the sortation criterion based on seed size will be able to narrow genetic diversity (Singh et al. 2011).

Genetic factor is also indicated by some studies which were exploring the relationship of seed size and provenance (Ager and Stettle 1983; Singh et al. 2011; Munthali et al. 2012; Shankar and Synrem 2012; Munthali et al. 2012; Guan et al. 2013; Abdelbasit et al. 2014; Fredrick et al. 2015; Mkwezalamba et al. 2015). Some characteristics of fruit and seed are influenced by environmental factors too, such as altitude, temperature and agronomic practices (Quarda et al. 2008). High temperatures have a negative impact on the seed size of Acer platanoides (Caron et al. 2014). Abdelbasit et al. (2014) stated that seed size variation reflected the genetic variation and its adaptation towards different environmental condition. Therefore, removing small-sized seeds has a potency to eliminate generation that might have adapted to certain environments.

Up to now, detailed information on the influence of seed size towards seed and seedling qualities has not been available yet. In this case, the results are necessary to provide the available sortation technique based on seed size, so it is to avoid loseness. In addition, the factors affecting seed size are important basic information for determining seed collection technique to get high-quality seeds. The study is aimed to determine the variation of 
mahogany (Swietenia macrophylla) seed sizes and its effect on the germination and seedlings growth.

\section{MATERIALS AND METHODS}

\section{Study area}

The seeds and fruits were collected in May 2016 from 1996 mahogany stands at Forest Research of Parung Panjang, Bogor, Indonesia ( $106^{\circ} 30^{\prime}$ E.L and $06^{\circ} 22^{\prime}$ ' S.L.), and in June 2016 from 1999 mahogany stands at Cariu Forest Resort, Bogor Forest Resort Unit, Bogor, Indonesia (106 '44' E.L and $06^{\circ} 31^{\prime}$ 'S.L) (Figure 1). Seeds were sown in June 2016 and germination was observed from August to September 2016. The germinating seedlings were replanted in September 2016 and the observation of seedling growth was ended in December 2016.

\section{Procedures}

The variation of seed size inside the fruit, among fruit and among trees

A number of ten fruits were randomly withdrawn from a collection of samples of fruit collected from several trees. Each of the sample fruits were then weighed, measured in length and diameter, and the number of filled and empty seeds inside the fruit were counted. To measure the dimension of seed, a number of 20 fruits were used as a representative of fruit sizes (117.4 to $172.9 \mathrm{~mm}$ long and 69.8 to $99.5 \mathrm{~mm}$ wide) collected from 5 sample trees. Fruits were opened and the seeds were measured in length, width and the positions of seeds inside the fruit were observed. The total number of observed seeds was 1021 .
Seeds were classified into 5 classes according to length, namely: 1) $<6 \mathrm{~cm}, 2) 6-6.9 \mathrm{~cm}, 3) 7-<7.9 \mathrm{~cm}$, 4) $8-8.9 \mathrm{~cm}$ and 5) $<8.9 \mathrm{~cm}$. There were 50 sample seeds taken randomly from each size class and replicated 4 times. The percentage of seed number in each class to the total number of seeds was counted, as well as the number of filled and empty seeds.

\section{The influence of seed size on germination and seedling growth}

Each replication of seeds from different class was sown on sandy soil media (50: $50 \mathrm{v} / \mathrm{v})$ and put in a green-house for two months. The observed parameters were germination capacity (GC) and germination rate (GR). When the germinating seedlings were 2 months old after the day of sowing, they were replanted into polybags and their growths were observed. There were 20 seedlings being observed and replicated 4 times. The evaluation of growth was carried out every 3 weeks, until the seedlings were 3 months old. The evaluated parameters were total height and stem diameter of seedlings.

\section{Data analysis}

The features of seed size diversity are shown by distribution charts and descriptive analysis. Analysis of variance (ANOVA) was used to determine the factors influencing seed variation. The relationship between fruit size and seed size was analyzed by Pearson correlation at the 0.05 level by using software of Minitab 15 and SPSS 23.0.

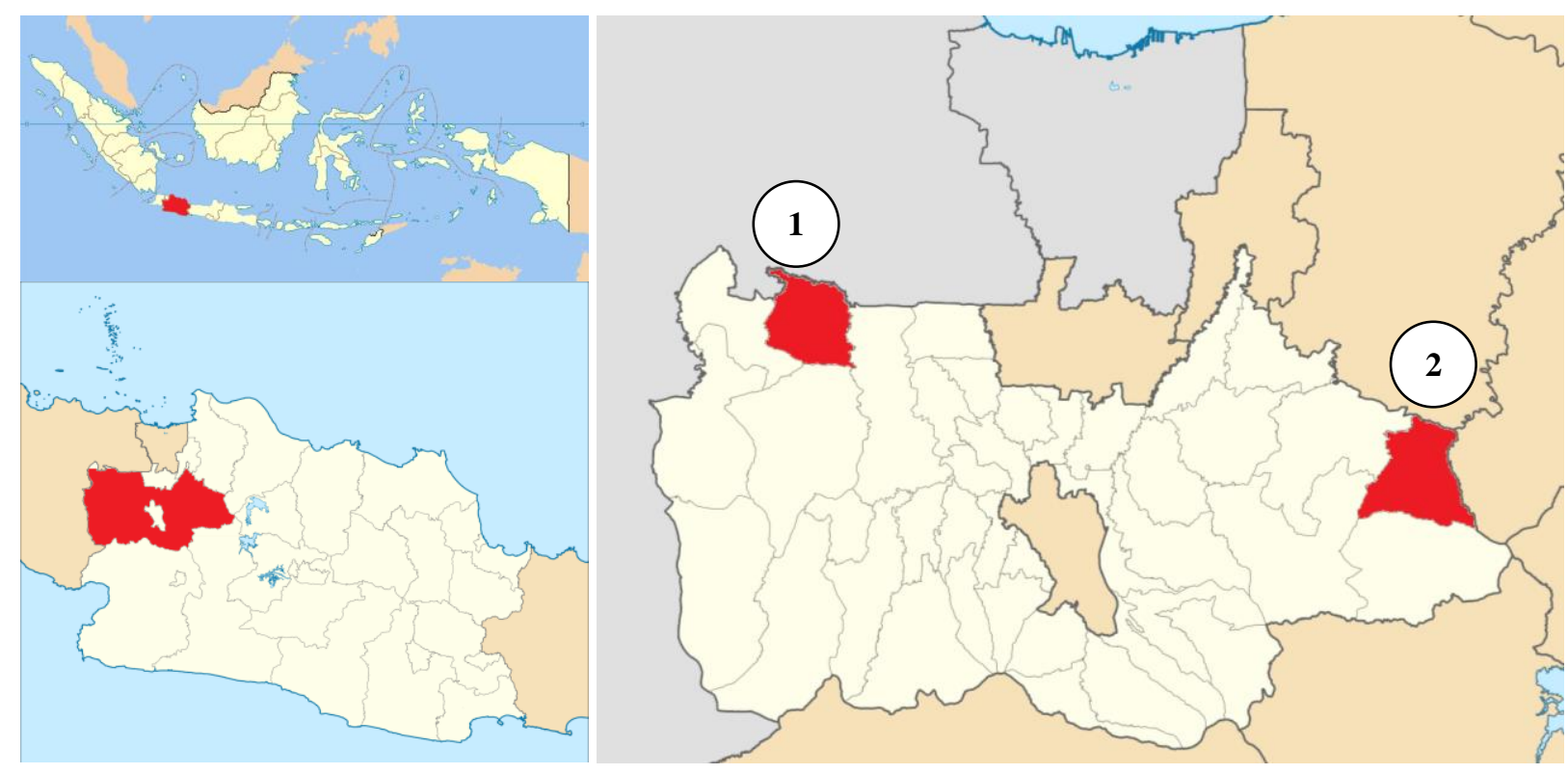

Figure 1. Location of mahogany stands was Research Forest of Parung Panjang (1) and Cariu Forest Resort (2), Bogor, West Java, Indonesia 


\section{RESULTS AND DISCUSSION}

The variation of seed size inside the fruit, among fruit size, and among mother trees

The mahogany seeds have a length ranging from 1.5 to $11.0 \mathrm{~cm}$ or $7.82 \pm 1.65 \mathrm{~cm}$ on average and most are in size of $9.0 \mathrm{~cm}$. Seeds width are in a range of $0.5-3.5 \mathrm{~cm}$ or 2.12 $\pm 0,47 \mathrm{~cm}$ in average and most are in $2.0 \mathrm{~cm}$ wide. The frequency of distribution of seed length and width is normal (Figure 2).

The observation of 20 fruits from 5 mother trees showed that, in average, the seed size was correlated to the fruit size. The length of seeds was positively correlated to the length of fruits, but did not correlate significantly to the width of the seeds. The width of fruit was significantly correlated to the width of seed (Table 1).

The correlation between fruit size and seed size of mahogany indicates that the fruit size may be able to be a good indicator to predict the size of seed. The relationship between fruit width $\left(\mathrm{F}_{\mathrm{w})}\right.$ and seed width $\left(\mathrm{S}_{\mathrm{w}}\right)$ of mahogany (Figure 3$)$ is formulated in an equation of $\log 10\left(\mathrm{~S}_{\mathrm{w}}\right)=-$ $0.9462+0.6599 \log 10\left(\mathrm{~F}_{\mathrm{w}}\right)$, meanwhile relationship between fruit length $\left(F_{1}\right)$ and seed length $\left(S_{1}\right)$ is figured in an equation of $\mathrm{S}_{1}=-13.88+10.11 \log 10\left(\mathrm{~F}_{1}\right)$. The positive relationship between fruit size and seed size is similar to other studies such as on Balanites aegyptiaca (L.) tree (Abasse et al. 2010).

The result indicates that the factors influencing fruit size will significantly influence the seed size. Various studies reveal factors that might affect fruit size. Harper (1970) reported the relation of produced-fruit per tree and fruit size. In the limited availability of nutrition resources, plants will allocate the available resources for the production of large seeds in a less number or, otherwise, in a large number production of smaller seeds. When the success of fertilization was high, the increase of nutrition competition will occur, so the fruit form becomes smaller. The correlation between fruit number and seed size was shown in the study of Acacia senegal (sym. Senegalia senegal) where the tree with a larger number of branches is associated with smaller seeds product (Chiveu et al. 2009). This shows that the size of the fruit is influenced by internal factors such as the success of reproduction and by environmental factors such as the availability of nutrients. Coutts et al. (2012) revealed that Pinus nigra produced more seeds when the condition of environment was dry and windy that potentially would increase the proportion of scattered-seeds in a far distance (Coutts et al. 2012).

Table 1. The analysis of Pearson correlation between fruit size and seed size of mahogany

\begin{tabular}{lcc}
\hline & Fruit length & Fruit width \\
\hline Seed length & $0.731^{* * *}$ & $-0.214^{\mathrm{ns}}$ \\
Seed width & $-0.357^{\mathrm{ns}}$ & $0.591^{* *}$ \\
\hline
\end{tabular}

Note : $\mathrm{ns}=$ non significant correlation at level of $5 \% ; * *=$ significant correlation at level of $1 \%$
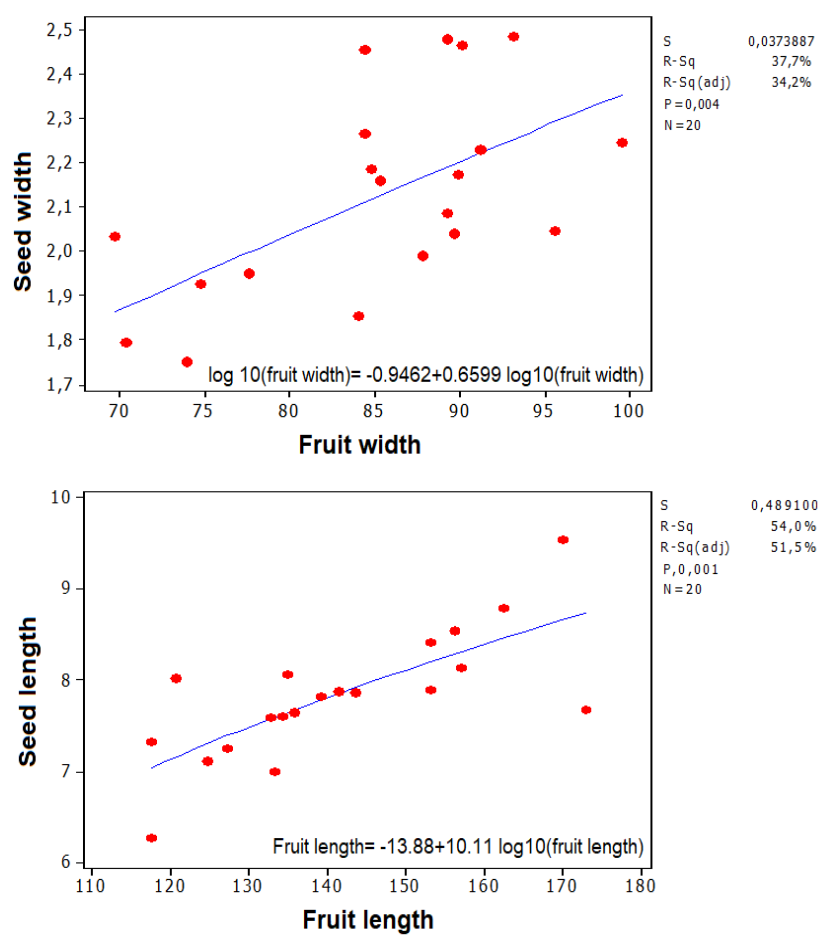

Figure 3. Relationship between fruit size and seed size of mahogany

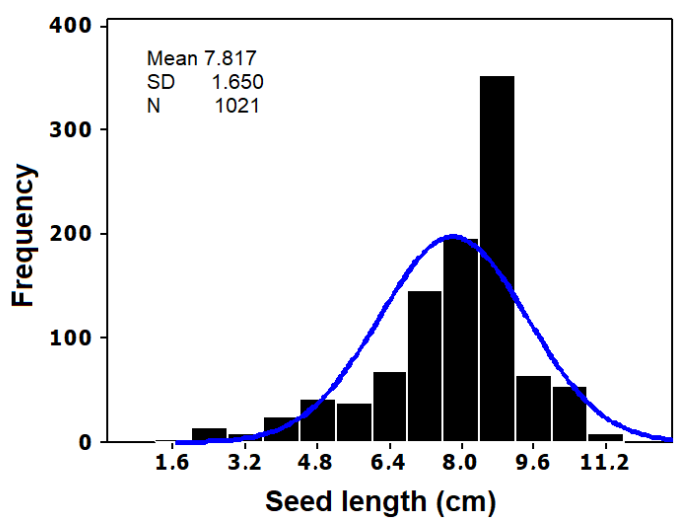

Figure 2. The distribution frequency of mahogany seed length and width 
The relationship between fruit size and environmental condition is also found on Vitellaria paradoxa, where the size was influenced by agroecology zones (Ugese et al. 2010). The cone characteristic of Pinus wallichiana shows a significant correlation to geographical factor namely longitude, latitude and altitude (Rawat and Bakshi 2011). Several morphological characteristics of Ceratonia siliqua fruit are influenced as well by environmental factors such as altitude, temperature and agronomic practices (Ouarda et al. 2008).

Mahogany fruit is a capsule-shaped fruit contained 5 loci. Each locus contains seeds that range from 11 to14 seeds, lined with 2 rows and stacked (Figure 4). The observation showed that the size of seed is strongly influenced by the position of seeds inside the locus. The analysis of variance showed significant differences in the length and width of seed among the seeds that are in different positions in the locus (Table 2).

The analysis result showed that the seeds located at the outermost position (furthest from the stalk or position no. 1) were significantly the shortest seed and gradually increase in length to the fifth outermost position. The position of seed did not influence its size as long as the position was at the seventh to thirteenth. At such position, the seed has the longest size. At the fourteenth position, the closest to the fruit stalk, the seed size was shortened (Figure 5).

In case of seed width, the seed at the outermost was significantly had the lowest width. Up to the fifth outermost, the closer position to fruit stalk will produce wider seed than on other position. The position of seed did not influence its size as long as the position was at the sixth to the tenth. At such position, the seed has the widest size. The seed width will be decreased at eleventh to fourteenth position.

The influence of seed position on their size was found in Alliaria petiolate. The fruits located at a basal part of fruit stalk have wider seeds than those located at the end of the stalk (Susko and Lovett-Doust 2000). The finding showed that fruits and seeds were competed in obtaining photosynthate from the mother trees. Seeds at the farthest position from the main stem or located at the end of the stalks have the lowest chance to win the competition in getting nutrients from their mother, so that they have the smallest size.

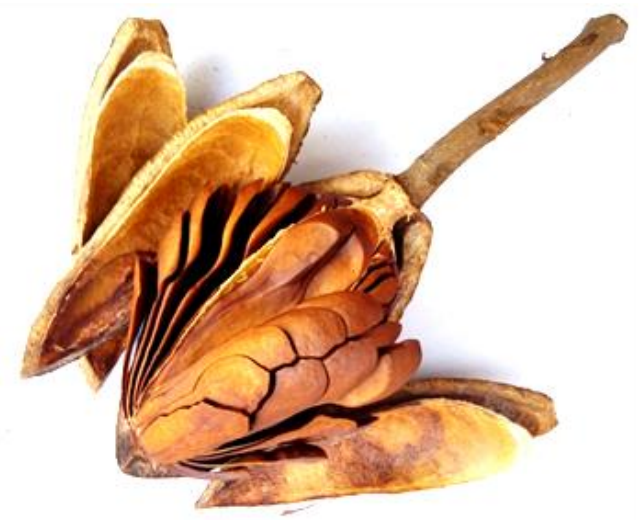

Figure 4. The position of seeds within the fruit of mahogany
Table 2. The analysis of variance of the effect of seed position within fruit and among mother trees on its size

\begin{tabular}{lcc}
\hline & Within fruit & Among mother trees \\
\hline Seed length & $62.97 * *$ & $3.96 *$ \\
Seed width & $37.49 * *$ & $16.29 * *$ \\
\hline
\end{tabular}

Note: $*=$ significance at $5 \%$ level; $* *=$ significance at $1 \%$ level
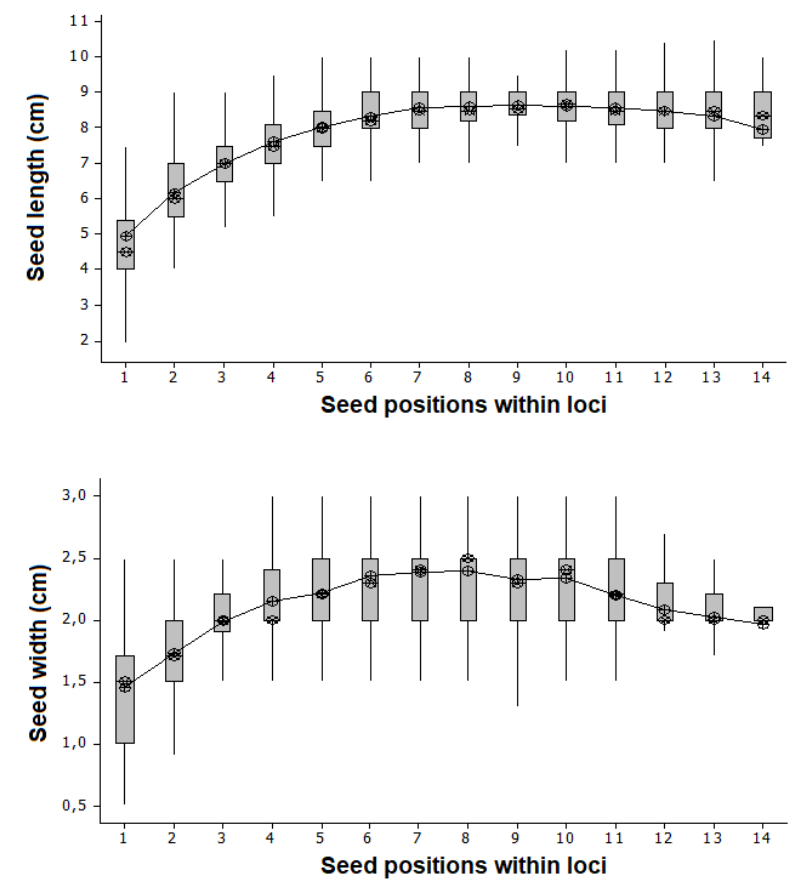

Figure 5. The change of length and width in relation to the seed position within a locus of mahogany

The study showed that the difference of mahogany seed size may happen due to the differences of seed position inside the fruit which are not related directly to the quality of the mother trees. The flowers pollinated by pollens from the same parent tree might produce seeds with high variety of different size when the fertilized ovules are in different position within loci. Therefore, seeds resulted from the same parent trees will have a chance to produce high variety of different seed sizes, even though they have an equivalent genetic quality. In addition to the position of seeds in the locus, the observation revealed that there were significant differences in seed length and width among mother trees (Table 2). This indicates that the variation of mahogany seed sizes is also under genetic control. Such result was found on several other species too. In Balanites aegyptiaca, all variables of fruit and seed size varied significantly among trees (Abasse et al. 2010). As well as, research results on Dalbergia sissoo Roxb, (Singh et al. 2011), Acacia tortilis (Abdelbasit et al. 2014), Pinus ponderosa (Agera and Stettle 1983), Adansonia digitata (Munthali et al. 2012) and Prunus nepaulensis (Shankar and Synrem, 2012) showed that the clonal effect was dominant on the size and weight of seeds. In fact, the seed 
size, related to genetics other than indicated by clones, is also shown by the relation of seed size and provenance, for instance on Jatropha curcas (Guan et al. 2013), Adansonia digitata L. (Munthali et al. 2012). Sclerocarya birrea (Mkwezalamba et al. 2015) and Faidherbia albida. (Fredrick et al. 2015).

\section{The influence of seed size on filled seeds, germination, and seedling growth}

The result showed that seed size influenced significantly $(\mathrm{p}<0.001)$ on the germination capacity. The highest germination capacity $(73.8 \%+10.34 \%)$ was achieved from the medium seeds size (length of 7 to $<7.9$ $\mathrm{cm})$ and the lowest germination capacity $(32.5 \% \pm 6.86 \%)$ was obtained from the smallest seeds size (length of $<6$ $\mathrm{cm}$ ) (Table 3). The rate of germination was significantly different among seed size. The rate of seed length of $<6$ $\mathrm{cm}$ was significantly slower than those seeds of bigger size. In this case, the bigger seeds are likely to have more available nutrition reserves to support germination process.

This result is in line with several other research results. The rate of germination of Terminalia arjuna was increasing along with the increase of seed size (Kumar et al. 2017), in addition, the germination of Pongamia pinnata had a positive correlation to seed width (Divakara et al. 2010). In the case of nyamplung (Calophyllum inophyllum), the small seeds have higher germination rate than large seeds (Hasnah. 2013). Rubber (Hevea brasiliensis) seeds size significantly affected their germination rate and capacity (Bahri and Saukani 2017). The seed weight of merbau (Intsia bijuga) has a positive effect on germination success (Wulandari et al. 2015). As well as, the small seeds of herb plant of Thlaspi arvense possess lower germination capacity instead of medium and large seeds (Susko and Cavers 2008).

Contrary to the results of this study, Mimusops elengi (Suita and Nurhasybi 2008) and Dalbergia sissoo (Singh et al. 2011) were reported to have different result, namely that their seeds size did not show a different effect on their germination capacity. Likewise, the seeds of soybean showed that the large seeds possessed a lower seed amount and germination capacity than those of medium and smaller seeds (Yulyatin and Diratmaja. 2015).

The seeds size affected the initial growth of seedlings. Stem diameter of the seedlings was significantly different at the third and ninth weeks, while the height of the seedlings was different significantly at the third, sixth and ninth weeks (Table 4). The observation at the third week, the small seeds $(<7 \mathrm{~cm}$ long) produced larger diameter of seedlings but shorter in height than those seedlings from medium seed size (7-9 cm long). At the third and ninth weeks, the seedlings from seed size of $>9 \mathrm{~cm}$ have a low growth rate. At the twelfth week, the size of the seedlings (stem diameter and height of seedlings) was not significantly different among all the seed sizes (Table 4). Thus, the size of mahogany seeds does not affect the growth of seedlings which are ready for planting.

Table 3. Mean values of germination viability parameters of mahogany in relation to different seed size

\begin{tabular}{cccc}
\hline $\begin{array}{c}\text { Seed size } \\
\text { classes } \\
(\mathbf{c m})\end{array}$ & $\begin{array}{c}\text { Filled seeds } \\
\text { percentage } \\
(\boldsymbol{\%})\end{array}$ & $\begin{array}{c}\text { Germination } \\
\text { capacity } \\
\text { percentage } \\
(\boldsymbol{\%})\end{array}$ & $\begin{array}{c}\text { Germination } \\
\text { rate percentage } \\
(\% / \text { etmal })\end{array}$ \\
\hline$<6$ & $17.8 \pm 6.19 \mathrm{a}$ & $32.5 \pm 6.86 \mathrm{a}$ & $1.61 \pm 0.33 \mathrm{a}$ \\
6 to 6.9 & $25.4 \pm 11.42 \mathrm{a}$ & $59.5 \pm 7.33 \mathrm{~b}$ & $3.03 \pm 0.35 \mathrm{~b}$ \\
7 to $<7.9$ & $81.9 \pm 3.28 \mathrm{~b}$ & $73.8 \pm 10.34 \mathrm{c}$ & $3.52 \pm 0.64 \mathrm{~b}$ \\
8 to 8.9 & $95.5 \pm 2.34 \mathrm{bc}$ & $56.8 \pm 9.36 \mathrm{~b}$ & $2.79 \pm 0.49 \mathrm{~b}$ \\
$<8.9$ & $86.1 \pm 6.90 \mathrm{c}$ & $61.8 \pm 9.57 \mathrm{bc}$ & $3.15 \pm 0.48 \mathrm{~b}$ \\
F-Value & $115.80 * *$ & $11.76 * *$ & $9.35 * *$ \\
\hline
\end{tabular}

Note: $* *=$ significance at $1 \%$ level

Table 4. Analysis of variance of the effect of seed size on the growth of mahogany seedlings at four periods of observation

\begin{tabular}{lcccc}
\hline \multirow{2}{*}{ Response } & \multicolumn{4}{c}{ The time after planting (weeks) } \\
\cline { 2 - 5 } & $\mathbf{3}$ & $\mathbf{6}$ & $\mathbf{9}$ & $\mathbf{1 2}$ \\
\hline Diameter & $5.641^{*}$ & $1.025 \mathrm{~ns}$ & $4.799^{*}$ & $1.236 \mathrm{~ns}$ \\
Height & $5.518^{*}$ & $3.823^{*}$ & $3.334^{*}$ & $2.679 \mathrm{~ns}$ \\
\hline
\end{tabular}

Note: $*=$ significance at $5 \%$ level; $\mathrm{ns}=$ non significance at $1 \%$ level

Table 5. Stem diameter and seedling height of mahogany of each seed size class at four periods of observation

\begin{tabular}{lccccc}
\hline \multirow{2}{*}{ Respons } & \multirow{2}{*}{ Seed length $(\mathbf{c m})$} & \multicolumn{4}{c}{ Time after planting (weeks) } \\
\cline { 3 - 6 } & $\leq 6$ & $\mathbf{3}$ & $\mathbf{6}$ & $\mathbf{9}$ & $\mathbf{1 2}$ \\
\hline Stem diameter $(\mathrm{mm})$ & $>6-7$ & $2.53 \pm 0.17 \mathrm{bc}$ & $2.59 \pm 0.20$ & $3.04 \pm 0.13 \mathrm{bc}$ & $3.37 \pm 0.20$ \\
& $>7-8$ & $2.26 \pm 0.07 \mathrm{c}$ & $2.73 \pm 0.12$ & $3.17 \pm 0.15 \mathrm{c}$ & $3.50 \pm 0.16$ \\
& $>8-9$ & $2.28 \pm 0.17 \mathrm{ab}$ & $2.50 \pm 0.11$ & $3.07 \pm 0.11 \mathrm{bc}$ & $3.56 \pm 0.17$ \\
& $>9$ & $2.13 \pm 0.14 \mathrm{a}$ & $2.57 \pm 0.24$ & $2.85 \pm 0.21 \mathrm{ab}$ & $3.39 \pm 0.22$ \\
& & & & $2.78 \pm 0.11 \mathrm{a}$ & $3.33 \pm 0.13$ \\
Height & $\leq 6$ & $21.96 \pm 0.92 \mathrm{a}$ & $24.68 \pm 1.14 \mathrm{ab}$ & $27.29 \pm 1.06 \mathrm{ab}$ & $29.91 \pm 0.77$ \\
$(\mathrm{~cm})$ & $>6-7$ & $23.35 \pm 1.19 \mathrm{ab}$ & $25.58 \pm 1.18 \mathrm{ab}$ & $28.02 \pm 1.34 \mathrm{ab}$ & $31.00 \pm 1.62$ \\
& $>7-8$ & $24.90 \pm 1.55 \mathrm{~b}$ & $26.71 \pm 1.39 \mathrm{~b}$ & $29.27 \pm 1.42 \mathrm{~b}$ & $31.91 \pm 1.46$ \\
& $>8-9$ & $24.80 \pm 1.41 \mathrm{~b}$ & $26.76 \pm 1.30 \mathrm{~b}$ & $28.92 \pm 1.84 \mathrm{~b}$ & $31.22 \pm 1.87$ \\
\hline
\end{tabular}

Note: $*=$ significance at $5 \%$ level; $\mathrm{ns}=$ non significance at $1 \%$ level 
It is revealed from this study that the larger seeds size is not followed by the higher germination capacity. The seed size only affects the early growth of seedling (up to 3 months old). The result is different from many studies of other species of plants. Mostly larger seeds produce higher germination, seedling growth rate and percentage of seedling survival such as Mimusops elengi (Suita and Nurhasybi 2008), Thlaspi arvense (Susko and Cavers 2008), Macadamia integrifolia (Heryana et al. 2008), Terminalia arjuna (Kumar et al. 2017), legume (Arellano and Peco 2012) and Calophyllum inophyllum (Hasnah 2013).

However, in a natural condition, the rapid growth of seedlings due to their bigger size of seeds does not always give an advantage. Arellano and Peco (2012) who studied on legume species said that large seeds provide benefits for seedling survival, but in extreme drought conditions, seedling survival was just the same between those grown from small seeds and big seeds. Seedling from bigger seed do produce larger seedling, but, under extreme drought condition, has a lower root/shoot ratio that causes greater potential of evapotranspiration, thus eliminates its relative advantages.

On certain species, small seed does not always produce worse growth of seedling. For example, rubber seed of medium size gave higher germination percentage and seedling growth than the bigger ones (Bahri and Saukani 2017). Seed size of Dalbergia sissoo did not give a significant correlation to the growth of its seedling (Singh et al. 2011). There was a big variation of within and among seed sources of Pinus wallichiana in term of seedling quality (Rawat and Bakshi 2011). Seed biomass of Pinus sylvestris was correlated positively to the initial growth of seedlings (76 days after sowing), but subsequent seedling growth at 10 months was not significantly different (Castro 1999). On Alliaria petiolata, the size of seed does not influence the growth of seedling (Susko and Lovett-Doust 2000). As well as, the seedling characters of Pithecellobium pedicellare are not related to the weight of seed, but more affected by genetic factor from the parent (Kang et al. 1992).

The study indicated that large seeds of mahogany possessed big cotyledons which only had a positive role to support germination. This was presumably due to its dependence on food reserves in cotyledons for germination growth. However, when the seedlings have been able to use food from photosynthesis, then all seedlings have the same opportunity to grow. The small seeds of mahogany (especially $<6 \mathrm{~mm}$ in size) do produce seedlings that are not different from larger seeds. However, the small seeds have weakness such as the low percentage of filled seeds, germination capacity and rate. Therefore, seed sortation on mahogany might be done by removing small seeds of less than $6 \mathrm{~mm}$ in size. The loss of genetic variation is probably not a significant problem, because the result of the study have showed that the number of small seeds of $6 \mathrm{~mm}$ in size was only $12.5 \%$ of the total number of seeds and only $18.6 \%$ of filled seeds, and it's only about $32.5 \%$ of filled seeds which were germinated (Table 4 ). If the seeds of $<6$ $\mathrm{mm}$ in size were removed, then the viable seeds which were wasted were only $0.76 \%$ of the total number of seeds.

In conclusion, seed variation of mahogany is caused by the influence of seed position inside the fruit, parent trees, and fruit size. Seeds of $<6 \mathrm{~mm}$ in size have significantly lower germination rate and capacity than larger seeds. Seed size has a significant effect on seedling growth in the early stages of growth, but does not affect the size of the seedlings when the seedlings are 3 months old. Seed sortation could be done by removing seeds that are below 6 $\mathrm{mm}$ in size.

\section{ACKNOWLEDGEMENTS}

Appreciation is addressed to Director and staffs of Forest Tree Seed Technology Research and Development Centre, Bogor, Indonesia that provide funding and facilities of this research project. Our sincere and deep thanks are expressed to all of the team members for their help, patience and kindness to fulfill and finish all the jobs required to undertake this research.

\section{REFERENCES}

Abasse T, Katkore B, Larwanou M et al. 2010. Morphological variation in Balanites aegyptiaca fruits and seeds within and among parkland agroforests in eastern Niger. Agrofor Syst 81 (1): 57-66.

Abdelbasit, Elmagboul H, Mahgoup S, ElDoma A. 2014. Variation in seed morphometric characteristics and germination of Acacia tortilis subspecies raddiana and subspecies spirocarpa among three provenances in Sudan. Global J Biotechnol 3 (2): 191-196.

Ager AA, Stettle RF. 1983. Local variation in seeds of ponderosa pine. Can J Bot 61: 1337-1344.

Arellano G, Peco B. 2012. Testing the role of seed size in annual legume seedling performance under experimental autumn moisture conditions. J Veg Sci 23 (4): 690-697.

Bahri S, Saukani. 2017. The effect of seed size and media on germination and seedling growth of karet (Hevea brasiliensis Muell. Arg.). J Agrosamudra 4 (1): 58-70.

Carón MM, De Frenne P, Brunet J. 2014. Latitudinal variation in seeds characteristics of Acer platanoides and A. pseudoplatanus. Plant Ecol 215 (8): 911-925.

Castro J. 1999. Seed mass versus seedling performance in Scots pine: a maternally dependent trait. New Phytol 144 (1): 153-161.

Chiveu CJ, Dangasuk OG, Omunyin ME et al. 2009. Quantitative variation among Kenyan populations of Acacia senegal (L.) Willd. for gum production, seed and growth traits. New Forests 38 (1): 1-14.

Coutts SR, Caplat P, Cousins K et al. 2012. Reproductive ecology of Pinus nigra in an invasive population: individual-and populationlevel variation in seed production and timing of seed release. Ann For Sci 69 (4): 467-476.

Divakara BN, Alur AS, Tripati S. 2010. Genetic variability and relationship of pod and seed traits in Pongamia pinnata (L.) Pierre. a potential agroforestry tree. Intl J Plant Prod 4 (2): 129-141.

Fredrick C, Muthuri C, Ngamau K et al. 2015. Provenance variation in seed morphological characteristics. germination and early seedling growth of Faidherbia albida. J Hortic For 7 (5): 127-140.

Guan J, Yu H, Zhang J et al. 2013. Study on Seed Morphology and Genetic Diversity of Jatropha curcas L. from Different Provenances Advance. Intl J Food Sci Technol 5 (2): 169-173.

Harper JL, Lovell E, Moore KG. 1970. The shapes and sizes of seeds. Ann Rev Ecol Syst 1 (1970): 327-356.

Hasnah TM. 2013. Pengaruh ukuran benih terhadap pertumbuhan bibit nyamplung (Calophyllum inophyllum L.) . Wana Benih 14 (2): 119134. [Indonesian] 
Heryana N, Rusli, Indriati G. 2008. Pengaruh ukuran benih terhadap pertumbuhan bibit makadamia (Macadamia integrifolia). Agrin 12 (1): 35-41. [Indonesian]

Kang H, Jaschek G, Bawa KS. 1992. Variation in seed and seedling traits in Pithecellobium pedicellare a tropical rain forest tree . Oecologia 91 (2): $239-244$

Kelly BA, Gourlet-Fleury S, Bouvet J. 2007. Impact of agroforestry practices on the flowering phenology of Vitellaria paradoxa in parklands in southern Mali. Agrofor Sys 71: 67-75.

Kumar H, Lal SB, Wani AM et al. 2017. Seed Size Correlates with Germination Traits in Terminalia arjuna Genotypes. Intl J Curr Microbiol App Sci 6 (8): 2896-2903.

Lombardo JA, McCarthy BC. 2008. Silvicultural treatment effects on oak seed production and predation by acorn weevils in southeastern Ohio. For Ecol Manag 255 (7): 2566-2576.

Mkwezalamba I, Munthali CRY, Missanjo E. 2015. Phenotypic variation in fruit morphology among provenances of Sclerocarya birrea (A. Rich.) Hochst. Intl J For Res 2015: 735418. DOI: 10.1155/2015/73541.

Munthali CRY, Chirwa PW, Akinnifesi FK. 2012. Phenotypic variation in fruit and seed morphology of Adansonia digitata L. (Baobab) in five selected wild populations in Malawi. Agrofor Syst 85 (2): 279-290.

Norghauer JM, Nock CA, Grogan J. 2011. The importance of tree size and fecundity for wind dispersal of big-leaf mahogany. PLoS ONE 6 (3): e17488. DOI: 10.1371/journal.pone.0017488.

Okullo JBL, Hall JB, Obua J. 2004. Leafing. flowering and fruiting of Vitellaria paradoxa subsp. nilotica in savannah parklands in Uganda. Agrofor Syst 60 (1): 77-91

Ouarda HE, Naghmouchi S, Walker DJ et al. 2008. Variability in the pod and seed parameters and nuclear DNA content of Tunisian populations of Ceratonia siliqua L. Agrofor Syst 74 (1): 73-81.

Pramono AA, Palupi ER, Siregar IZ, Kusmana C. 2016. Characteristics of Surian Flower. Fruit and Seed Productions (Toona sinensis (A. Juss.) M. Roem.) in Sumedang, West Java. Trop Life Sci Res 27 (1): 77-91.
Ratnaningrum YWN, Indrioko S. 2015. Response of flowering and seed production of sandalwood (Santalum album Linn. Santalaceae) to climate changes. Procedia Environ Sci 28 (2015): 665-675.

Rawat K, Bakshi M. 2011. Provenance variation in cone, seed and seedling characteristics in natural populations of Pinus wallichiana A.B. Jacks (Blue Pine) in India. Ann For Res 54 (1): 39-55.

Shankar U, Synrem IL. 2012. Variation in morphometric traits of fruits and seeds of Prunus nepaulensis Steud. in Meghalaya, India. Trop Ecol 53 (3): 273-286.

Singh O, Sofi AH. 2011. Clone variation of seed traits. germination and seedling growth in Dalbergia sissoo Roxb. clonal seed orchard. Ann For Res 54 (2): 139-149.

Suita E, Nurhasybi. 2008. Pengaruh ukuran benih terhadap perkecambahan dan pertumbuhan bibit tanjung (Mimusops elengi L.). Jurnal Manageman Hutan Tropika 14 (2): 41-46. [Indonesian]

Susko DJ, Lovett-Doust L. 2000. Patterns of seed mass variation and their effects on seedling traits in Alliaria petiolata (Brassicaceae). Am J Bot 87 (1): 56-66.

Susko DJ, Cavers PB. 2008. Seed size effects and competitive ability in Thlaspi arvense L. (Brassicaceae). Botany 86 (3): 259-267.

Takahashi A, Shimada T, Shibata M. 2011. Variation in seed production schedule among individual trees of a deciduous oak species Quercus serrata: its relation to seed characteristics. Plant Ecol 212 (9): 15271535 .

Ugese FD, Mbah BN, Baiyeri PK. 2010. Agroecological variation in the fruits and nuts of shea butter tree (Vitellaria paradoxa C. F. Gaertn.) in Nigeria. Agrofor Syst 79 (2): 201-211.

Wulandari W, Bintoro A, Duryat. 2015. Pengaruh ukuran berat benih terhadap perkecambahan benih merbau darat (Intsia palembanica). Jurnal Silva Lestari 3 (2): 79-88. [Indonesian]

Yulyatin A, Diratmaja IGPA. 2015. Pengaruh ukuran benih kedelai terhadap kualitas benih. Agros 17 (2): 166-172. [Indonesian] 